Title: Appraising tourism and hospitality service failure events: A Chinese perspective

Yun-Lok Lee

Lecturer

Southern Cross University

Beverley Sparks, PhD

Professor, Services Industry Research Centre \&

Department of Tourism, Leisure, Hospitality and Sport Management

Griffith University

PMB 50, GCMC, 9726

B.Sparks@griffith.edu.au 


\title{
Appraising tourism and hospitality service failure events: A Chinese perspective
}

\begin{abstract}
Tourism forecasts suggest that China is a growing tourism market to international destinations. It is likely that these tourists will encounter a range of service experiences and, at times, service failures or problems. Gaining an insight into how Chinese tourists interpret service failure events can help firms develop more effective service recovery strategies. This study aimed to explore the cultural values Chinese hold for service failure and service recovery, using means-end chain methodology. The analysis of 70 in-depth interviews found five key themes representing the values that were threatened in poor service situations. The attributes and consequences were analyzed, and then linked to the five values of “face”, “equity”, “value”, "harmony” and "junzi" aspiration. Implications for hospitality service recovery with Chinese customers are discussed.
\end{abstract}

\section{KEY WORDS}

Chinese, cultural values, service failure, service recovery, means-end chain. 


\section{INTRODUCTION}

Changing international tourism travel patterns since the early 1980s have revealed that an increasing number of outbound tourists come from the Asia-Pacific region. The Asia-Pacific region's rise to prominence in international tourism is apparent from recent tourism development and forecast reports, as outbound travel from the region grew at an average rate of 7\% between 1990 and 2000, which is more than Europe or the Americas (WTO, 2003). Furthermore, it is forecasted that the People's Republic of China (China) will emerge as one of the most significant outbound markets in the world by 2020 (World Tourism Organization, 2003). The Asia-Pacific marketplace is sizeable, but highly competitive, thus, those hospitality service firms that can best meet their guests' needs will gain a market share. As a result, there is a continuing need for destinations to be better equipped to understand and manage these tourists (Reisinger \& Turner, 2003).

Quality services imply fewer incidents of service flaws, but delivering flawless service is difficult and some service failures are unavoidable (e.g., Sparks, 2003). Evidence suggests that customers remember service flaws more readily than great service (Titz, 2001). Thus, to ensure that quality is perceived in services and critical incidents of service excellence are better remembered than flaws, a comprehensive understanding of service failure processes is needed. Since service flaws need to be effectively recovered in order to return customers to a state of satisfaction, a coherent service recovery strategy becomes an important component of a firm's service management approach. However, an understanding of customer perceptions about what matters in a service failure context is required before a recovery plan can be formulated, especially when dealing with international tourists. 
A firm's service recovery strategy (including the management of service failure events) must be culturally relevant, suggesting that it must have accurate insights into customers' culture as these values often determine preferences for problem management (Becker, 2000). Furthermore, as Yuksel and his associates (2006) note there is a need to investigate how consumers from non-western cultures respond to service failures. Their study compares respondents from Turkey, the Netherlands, Britain and Israel on attitudes toward consumer complaining behavior. The present study seeks to gain a deeper understanding of how Chinese people perceive service failure and/or recovery incidents, with a focus on tourism and hospitality product experiences. Ethnic Chinese dominate the population of China and Singapore and represent a large minority in Malaysia, ranking high in these countries’ socio-economic ladder (FitzGerald, 2002; Phang, 2000). Thus, as a growing travel population, they are likely to dominate the outbound travel numbers and, as such, deserve further investigation.

\section{Service Failure and Recovery}

Research in service management has highlighted the opportunity for firms to regain their customers' confidence, trust and loyalty through a service recovery strategy in the event of service failure (Johnston, 1995). Customers base their evaluations of quality on how well the initial service is managed, as well as on actions taken to re-align the service to meet guests’ expectations (Berry, 1995). Compared to tangible products (e.g., cars, refrigerators), tourism or hospitality services have a greater propensity to fail due to their intangible or experiential nature, as well as simultaneous production and consumption. These characteristics imply the impossibility of hospitality firms to always guarantee error-free services in advance, 
or for customers to 'sample service quality before buying'. Confusion may often exist as to what exactly has been promised when customers receive services compared to tangible products. Successful service also demands that customers' expectations match service providers' behavior, a difficult task to achieve “under the conditions of time pressure and inter-customer variability" (Sparks, 2003:3). Uncontrollable external factors such as customer late arrival or unexpected employee illness, may also impact negatively on service standards (Becker, 2000). The high level of human interaction in hospitality services, involving frontline staff of diverse cultural backgrounds who act as key agents in the distributive channels, can also give rise to variability in service quality, resulting in a greater likelihood for mistakes (Lewis \& Chambers, 1989). The aim of a service recovery effort is to return customers to a state of satisfaction or even to a 'state of delight' with a special recovery effort (Johnston \& Fern, 1999).

Researchers are interested in customers' evaluations of justice, which can impact on their level of satisfaction and loyalty (Hui \& Au, 2001). Originating from legal and organizational research, justice issues are increasingly being featured in research into service failure and service recovery management (Blodgett, Hill \& Tax, 1997; Goodwin \& Ross, 1989). As mentioned, due to the service characteristics (e.g. intangibility), it is harder for firms to deliver 'zero defects' service. This in turn may cause customers to question if their treatment by the firms has been fair when defects occur. Service failures such as inefficient or rude staff can evoke in customers a feeling of injustice with negative consequences for service firms. Thus, service researchers (see for example, Matilla \& Patterson, 2004; McColl-Kennedy \& Sparks, 2003) have turned to justice theories to better understand customers' assessments of justice pertinent to hospitality service failure and recovery events. Much of the extant 
literature has tended to focus more on understanding service failure and recovery from a Western perspective, thus leaving open questions about how those from other regions, such as Asia, perceive service failure and recovery.

\section{Leveraging Culture}

It is argued here that a firm's service management approach is one that is based on a better understanding of how customers from a different cultural source market make sense of, and assign meaning to, service failure events. To date, most insights about service failure and recovery issues are derived from Western societies and it is uncertain as to what extent such insights are generalizable across cultures. For example, Clarke (1990) notes that the principles of customer satisfaction derived from the studies of Western consumers are less appropriate for universal application, while Schutte and Ciarlante (1998) observe that the transposing of consumer behavioral theories across cultures has been ineffective unless modified to account for cultural differences. Studies show that customers of different cultures evaluate service quality differently (Becker, Murrmann, Murrmann \& Cheung, 1999; Mattila, 1999), and exhibit different complaint behavior in hospitality settings (Liu, Warden, Lee \& Huang, 2001). There is also evidence of cultural differences in the perception of service failure and service recovery provision (Magnini \& Ford, 2004; Wong, 2004), as well as justice perceptions in complaint handling (e.g., Mattila \& Patterson, 2004). Growing globalization produces a consumer base high in cultural diversity, and makes culture a critical consideration when managing customer relationships (Becker, 2000).

Interactions between customers and service providers consist of a mix of social, work and consumer behavior and, as such, it is reasonable to expect that customers' cultural orientations can influence how they experience and evaluate 
service failure and recovery (Becker, 2000) and make judgments regarding fair treatment (e.g. Mattila \& Patterson, 2004). For example, for Eastern cultures, the attributions made about the cause of a service failure (by customers) might be directed toward external forces such as luck or fate rather than internal factors under the control of the service provider. Such approaches are implemented in an effort to avoid conflict and maintain harmonious relationships.

Culture serves to differentiate one ethnic-cultural group from another (e.g., Chinese and Malay) in one national boundary, although one ethnic group (e.g., Chinese) may share similar cultural values across different national boundaries (de Mooij, 1998; Fan, 2000). These values may be so thoroughly inculcated in people that they may persist after exposure to other cultures (Wong \& Lau, 2001). For example, despite Western influence, Confucian values still persist in many Chinese and other Asian societies (Tan \& McCullough, 1985). Fan (2000:4) notes that a set of core cultural values exists for Chinese people, which are "unique and consistent, [having been] shaped by a tradition of 4000 years of history and maintained by the same language”, thus giving Chinese their basic identity. These views suggest that Chinese in China or overseas hold a set of common core cultural values which differentiates them from other ethnic groups. If core Chinese cultural values persist, as the literature seems to suggest, then they should still be evident in societies today. However, other studies argue that influential forces such as colonialism and its legacy, foreign education, media, economic modernism, travel and indigenous culture can and do moderate people's birth cultural values, which in turn impact on their consumer behavior (e.g., Schutte \& Ciarlante, 1998; Tse, Lee, Vertinsky \& Wehrung, 1988). The suggestion here is that cultural values are not static but are evolving over time. 
These views raise important questions regarding the prevalence of core Chinese cultural values and their impact on Chinese consumers' behaviors in situations of service failure and service recovery. Past work has provided useful insights into Chinese cultural values. For example, Kluckhohn \& Strodbeck (1961) developed a classification system for these values, while the Chinese Culture Connection (CCC) (1987) group identified broad dimensions of Chinese values. Bond (1996) offered a profile of such values and Fan (2000) revised CCC's work and came up with a new classification of Chinese cultural values (CCVs). Bond \& Hwang (1987) proffered insights into the social behavior of Chinese, while Kindle (1982) developed a theory for Chinese consumer behavior. This work is useful to the extent that it provides a point of reference on core Chinese values, but it is unclear on how prevalent these values are in current Chinese societies. To date, there is limited published work in English that examines the impact of prevalent Chinese cultural values on their behaviors as service customers. Although Yau's (1994) study has provided useful insights into the influence of these values on Chinese consumer behavior, this work was related to tangible products and not services or flawed service situations. Similarly, Thorelli's (1982) pioneer study of customer satisfaction/dissatisfaction and complaining behavior of Chinese in the PRC examined a failed product and not service. Chiu, Tsang \& Yang’s (1987) study, which examined the role of "face", situation and attitudinal antecedents in Chinese consumer complaint behavior, provided some useful insights on face-work issues.

Some recent work, which examined the influence of culture on Chinese customers' reactions in service failure and recovery situations in hospitality settings, has provided some helpful insights. For instance, Wong's (2004) cross-cultural study of the role of culture on customer behaviors, or Magnini \& Ford's (2004) study on the 
need for Western hotel corporations in China to adapt their service failure recovery training programs to meet the needs of Chinese customers. Others, like Warden, Liu, Huang \& Lee (2003), reported a need to manage outbound Chinese customers with care since service failure incidents were found to increase while abroad.

\section{Justice Theory}

A growing body of literature has applied justice theory to the investigation and understanding of service failure and recovery (see for example, Collie, Sparks \& Bradley, 2000; Mattila \& Patterson, 2004; Tax, Brown \& Chandrashekaran, 1998). Three forms of justice are usually cited as being the basis for forming judgements of fairness about an action (such as a response to a service failure). Distributive justice is usually defined as what the customer receives as an outcome of the recovery process. This could be a free drink voucher for slow restaurant meal service, an apology for a delayed flight, a replacement for an incorrect meal or incorrect drink order or waiving of room charges if the stay in the hotel was considered unsatisfactory. Procedural justice is concerned with the process used to resolve the problem. It may involve the policy used to arrive at a decision or the process of giving the customer some say in the way a problem is handled. Interactional justice concerns the manner in which the service problem is dealt with by service providers and the specific interactions between the service provider and the customer. This form of justice tends to include interpersonal sensitivity, treating people with dignity and respect, or providing explanations for the events.

Useful insights in the justice area can be gleaned from recent studies. For example, Hui \& Au (2001) revealed how Chinese and Canadian customers perceived justice 
and their likely post-complaint behavioral responses. Similarly, Mattila \& Patterson (2004) provided insight into the influence of culture on customers' perception of fairness and satisfaction in the service recovery process using Hofstede’s (1980) general cultural constructs. General cultural constructs are pertinent if the purpose of the study is to engage a broad cross-cultural comparison of customer behaviors but such constructs may perhaps be ineffective in detecting the nuances of customer's behavior in different situational contexts in cultural and justice studies (Morris \& Leung, 2000). They noted that recent trends in research on culture and justice evaluations tended toward greater "specificity in the conception of cultural influence" and encourage researchers to use more specific value dimensions, specific cultural norms and beliefs, when uncovering cultural nuances and characteristics unique to a given ethnic cultural group. Thus, given the paucity of literature on the influence of Chinese culture on perceptions of service failure and recovery, the present study aims to fill that gap. The study is not proposing to be a cross-cultural analysis of service failure, but rather an investigation into a specific ethic group.

\section{The Study}

The current study aims to ascertain the core cultural values for service failure and service recovery held by Chinese consumers. The study examines how Chinese describe and make sense of negative service events, with a particular emphasis on how this sense making activity links to core service value beliefs.

\section{METHOD}




\section{The Participants}

Seventy participants of Chinese ethnicity in China $(n=24)$, Singapore $(n=21)$ and Malaysia $(n=25)$ volunteered for the study. They ranged from 20 to 80 years old and were selected from a wide range of social and occupational backgrounds. A convenient sampling approach was adopted in the selection of participants, where research assistants in each country were instructed to seek volunteers that represented the stipulated backgrounds. All participants had traveled abroad before and were likely to travel abroad in the future. They indicated previous use of hospitality services, such as restaurants and accommodation, in an international environment.

\section{Procedure}

In-depth interviews took place in the participants’ countries using a qualitative approach based on the means-end chain or laddering theory (Reynolds \& Gutman, 1988). The means-end theory focuses on the cognitive linkages which connect consumers' values to service choices, represented by chains linking service attributes (means) to the consumer's desired consequences, and personal values (ends). Participants were asked to recall a service incident pertaining to service failure or recovery in a hospitality setting and to discuss this event. In line with means-end chain theory, participants were repeatedly probed at appropriate junctures on why certain issues, demeanor or manner of treatment by the service providers were important to them. This approach provided a way to uncover the deeper meanings participants attached to the actions associated with the service event. Each interview session was by appointment and took place in the participant's home or office at his/her convenience. At the conclusion of the interview, each participant was given a token gift and thanked. Interviews were conducted in English, Putong hua (Mandarin) 
or Hakka (a Chinese dialect) and tape-recorded with the participant's permission. Interviews in Chinese dialects were then translated into English and rechecked by a bilingual assistant, who was conversant with both Chinese dialects, but blind to the study to ensure an unbiased approach to the translations. Each interview took approximately forty-five minutes.

In the analysis phase, a second assistant, proficient with content analysis but blind to the aims of the study, first classified the raw data into three categories: attributes, consequences, and values. Attributes reflected aspects of the service failure event, such as slow service, a broken promise or rudeness. Consequences were primarily the feelings associated with the service failure event, such as anxiety, annoyance or discomfort. The value category was more abstract, representing the important and desirable end states that participants articulated as the core issue of value that was important within the context of the service event. Hence, this category tapped the deeper reasons why a customer might find a certain service event favorable or unfavorable.

Data were analyzed using the means-end approach. A means-ends chain was established for each respondent based on a service failure event they had experienced. Once these ladders had been recorded, summary codes were established using the content analysis. To assist with the tracking of respondents each participant was given a unique code. First, a letter to designate the country of the interview was attached, then an interviewee number was given and finally a four-digit number to represent the day of the interview was applied. So the following code: S101011 indicates the interview was conducted in Singapore, coded as interview number 10 and conducted on the $10^{\text {th }}$ of November; whereas C091310 indicates the interview was conducted in mainland Chinese, coded as 
interview number nine and conducted on the $13^{\text {th }}$ of October. All of the interviews were conducted within a three-month period from October through to December, 2001.

\begin{abstract}
RESULTS
Understanding the Reactions to Service Failure and Expectations in Recovery

Table 1 shows the content codes for each of the levels of attributes, consequences and values, as well as the number of times each was mentioned. Referring to the table, for example, it is evident that the rude service (attribute) received had caused the participant to experience anger as a result (consequence). This negative service incident ultimately violated the person's self-esteem (value ends). Ultimately, five key 'value' themes resulted from the analysis. Each theme is discussed and presented with a means-end illustrative diagram. Participants’ words presented as verbatim comments in the value themes are coded beginning with a letter indicating the country, then the number allocated for each interviewee and the day and month of the interview.
\end{abstract}

Insert table 1 about here

Value Theme One - Face Protection ${ }^{1}$

The first theme is concerned with the protection of one's own and other people's reputation, commonly known as "face protection". The largest number of participants mentioned that they highly valued "face protection" in service failure and service recovery situations (see Table 1). Chinese conceptions of 'face' include 'lian'

\footnotetext{
${ }^{1}$ Please see the Appendix - Glossary of Terms for definition of Chinese terminology used in this paper
} 
and 'mianzi', where 'lian' is the moral reputation of individuals and 'mianzi' is the social prestige and honor that the individuals may claim from society through their achievement and success (Hu, 1944). People employ "face protection" to ensure that their public conduct is in accordance with society's expectations, thus enabling them to play an integral part in society (Yang, Ho \& Yau, 1989). This is illustrated in the following case where participant C091310 recounted that she took her friend to a reputable restaurant for a birthday celebration and was misinformed about the corkage charge (to open wine brought along to the restaurant). Upon disputing it, she was threatened by a discourteous manager if corkage was not paid. The incident had embarrassed her, as she had to wrangle over a money issue (corkage charge) with the manager in public. This was especially embarrassing as she was hosting her friend. This, and the manager's discourtesy had caused her to lose face. This illustrative chain for "face protection" is shown in Figure 1. As can be seen, the attributes of a service failure pertaining to discourteous service and misinformation had produced negative consequences since these critical service incidents had spoiled the guest's birthday celebration and caused her much embarrassment, thus seriously threatening her public face (reputation), which she said was important to preserve.

Another aspect of “face protection" relates to protecting the other party's face. In the same representative case, the participant (customer) reported that she had not argued too much with the manager, even though she felt threatened and would have liked to have defended her case. When asked why, C091310 had said partly, to protect her own face and also to "give face..." or "gei mianzi” (in Chinese), as evidenced in her response: "I do care what others think of me, what sort of person I am...perhaps they think I have no 'jia jiao' (translated in Chinese to mean 'family 
education')...if I create a scene...[]) don't like to argue too much, as I might cause others to lose face...” and added: “[I] give face to the manager...”.

Common responses of other participants regarding 'face protection' were also noted. For example, M141211 said: "Protecting face is important to me as a Chinese, as well as upholding my family name”. M041211 told: "If I behave poorly in public, I will lose face”. S060611 said: "You never embarrass a (hotel) guest in front of his friend...I experienced a loss of face...”. M051211 remembered: “I was offended when she [hotel manageress] lectured me on how I should lock my door...you shouldn't embarrass a guest like that”.

These responses indicate that the issue of 'face protection' is highly important to Chinese customers. This finding highlights the need for service firms to address negative service events involving Chinese customers in a manner that is interpersonally sensitive (a form of interactional justice) (Bies \& Moag, 1986).

Insert Figure 1 about here

\section{Value Theme Two - Equity}

The second theme related to the issue of equity. Many participants expressed a desire to be treated fairly in a service exchange situation. This means getting the quality of service, which they believed, they had paid, as evidenced in the following responses. S020611 said: "I felt cheated...had paid a lot...they [service providers] weren't interested in our enjoyment at all”. "We'd have accepted less had it been cheaper, but for what we'd paid, we certainly expected better...it was unfair". M171411 noted: “I am only human...don't like being disadvantaged...what's fair is fair...”. "It was very unfair, we'd rung early to confirm, but they [the resort] didn't tell us that we would be wait-listed...had we known, we could have made alternative plan...We'd planned this holiday for a while...but it was spoiled". 
Participants also explained that they expected fair treatment in not just the original service failure but also in the correction of the error [service recovery], as indicated in these responses. M051211 opined: “It was only fair that she [hotel's night-duty manageress] responded to our call for help promptly [instead] we waited for 45 minutes and after several calls...she didn't even apologize...but lectured us on how to lock our door...”. S190711 commented: “If I'm not party to the mistake, I think it's fair that they should solve the problem satisfactorily...find me another room and give me a fair compensation...”.

Participants' common desire for equitable treatment is expressed in this representative case. A customer and his young family had arrived tired at an expensive hotel late at night to be given an unprepared room, which greatly inconvenienced them. Upon complaining, they had a long wait for the room to be remade, but merely received an apology. The customer reported that both the original service and the service recovery were unsatisfactory and they had been treated unfairly, especially when a high room tariff was paid. For recovery, he felt disappointed at not being given a replacement room or a room upgrade immediately as compensation. This case is presented in the illustrative chain as shown in Figure 2. In this example, the attributes of service failure include both the original failure (misallocation of a hotel room) and the failure to implement proper service recovery (inefficient housekeeping service).

Some participants also expressed the desire to be "zhonghe" when dealing with others, which is another aspect of equity. "Zhonghe" in Chinese means moderation, reasonableness and harmony. An important aim of Chinese classical education has always been to cultivate a 'reasonable man' (Tan, 1998). In the context of service failure and recovery, a reasonable man is one who shows restraint, and 
demands only what is fair and just. This sentiment is conveyed through the following responses: M011111 said: “You shouldn’t demand for more than what is fair...I think people generally know what is fair and what isn't...”. S030511 informed: “Don't calculate so clearly...give him [service provider] space to move and a good result is more likely”, while C041310 advised: “We shouldn't go to the extreme in what we asked for" and "a reasonable claim is one that does not cause others to suffer loss".

It appears from participants’ responses that a value similar to Adam’s (1965) ‘equity' principle of input-output has been used in interpreting negative service events. This finding suggested that Chinese people will use the 'equity' principle to obtain a service outcome commensurate with their input in a standard service encounter relationship (Bond \& Hwang, 1987).

Insert Figure 2 about here

Value Theme Three - Valued Customers

A third theme related to a desire to be respected as 'valued customers' in service exchange situations. Seven areas pertaining to the service provider's behavior which participants believed had an impact on their perceptions of being treated as 'valued customers' (see Table 1) are presented as follows.

The first area pertains to participants' perceptions of racial and social discrimination by the service providers. Participants' perceptions of being socially discriminated against are highlighted in the response: M081211 said: "They serve others first, although we were first...favored well-known people in town...really felt let down...”. In a representative case, a guest reported that although his party had 
arrived earlier than another party with guests of a different race, his party was served later. On complaining about the discriminatory treatment, the participant believed that the service provider gave him an insincere explanation. The illustrative chain presented in Figure 3 shows two attributes of service failure, delayed service and insincere explanation, which have resulted in the participant feeling indignant and racially discriminated. This ultimately caused him to feel that he was not being valued as a patron, as evidenced in this response: S100511 said: "I was very angry when they discriminated against me on racial ground...it's no way to treat a customer...[they] didn't value me for sure".

Insert Figure 3 about here

The second area pertains to the sincerity of the apology being extended by the service providers, as exemplified by participants’ responses: C071410 explained: “... an honest and sincere apology is a very important response from my server as this shows I'm valued as a customer”, while M221611 said: “I consider they value me more if they are sincere in their apologies". S200711 commented: “My faith is restored through sincere apology”.

A third area relates to the politeness and courtesy (limao) of the service providers. For example, C051310 said: “When I'm inconvenienced, they should all the more show 'limao' (politeness), [as] it's the essence of Chinese culture” or S030711 said: "If I behaved with propriety, I expect my service provider to do likewise when things need to be resolved"... "I couldn't tolerate the rude attitude of the staff [member, all the more if they are serving others". 
A fourth area is connected with participants' perceptions of the extent to which the service providers expended effort. It appears from the participants' responses that they perceived they were being treated as valued customers if service providers expended effort to help them resolve service failures. This is illustrated in the following responses: with C011210 lamenting: “They did little...showed just how much they valued me”; while S160811 explained: “They don't see me as important as I have to demand for things to happen."

The fifth area relates to participants being perceived as having genuine grounds for complaints. It appears that the participants felt like valued customers if service providers accepted their complaints as genuine, as demonstrated in these responses: S190911 recounted: “ [they] didn't seem to believe me, thought I lied...wonder how important I really was [to them]”, while M011111 remembered: “He gave me the impression [that] my complaint wasn't genuine as I was asked a lot of questions...felt insulted and small”.

Being treated with honesty is the sixth area valued by participants. For example, S170811 explained: “I would be angry if they didn’t admit [the] mistakes, although it was obvious to me they'd lied, what an insult!...it's clear I matter not”.

The final area identified by participants relates to customer's rights being respected, as these responses show. C111610 commented: “I paid my money, it's only fair that they should care about my interest as a guest...it would demonstrate [to me] they value my support ...it's important these days with the competition [as] it is...”. S010511 said: "Customers have rights, if they value me as a client, they must try to respect this”.

It appears that Chinese customers perceive themselves as being treated as a valued customer in negative service exchanges if service providers do not 
discriminate against them racially or socially, extend a sincere apology to them when mistakes occur, demonstrate an effort with service recovery, honour their rights, and deal with them in an honest, trusting and proprietary manner. Although these values may be universal, specific beliefs of people from different cultures may lead to different a interpretation of these values (see Morris \& Leung, 2000).

\section{Value Theme Four - “Junzi” (cultured person) Aspiration}

The fourth theme relates to the participants' aspiration to behave like a "junzi” when interacting with others. In the Confucian tradition, a "junzi" is a noble or cultured person, fully clothed with the virtue of "ren”, which is being benevolent or human towards all fellow human beings (Cheu, 2000, p.1). For example, a customer with a "junz"' behavior will gracefully accept a lower standard room and be tolerant towards the service provider although being disadvantaged, despite the fact that it is a one-sided affair. Figure 4 provides an illustrative chain of a participant's aspiration to be "junzi". The chain attributes pertain first to the misunderstanding resulting in the customer being given an inferior room (distributive injustice) and second to the rude and undignified treatment he had received from hotel staff in the process (interactional injustice). These attributes of the service failure event caused the customer to experience feelings of indignity and to suffer physical discomfort, which ultimately posed a threat to the customer's end value of being a "junzi".

\section{Insert Figure 4 about here}

When service fails and a dispute arises, an individual aspiring to be a "junz"” or cultured person may attempt to moderate his or her behavior to avoid 
confrontation. In the case previously illustrated, the guest's indignity resulting from the rude treatment by hotel staff and the discomfort of a small hotel room posed a threat to the "junz"' aspiration. This behavioral trait is also manifested in other cases gleaned from the study. Common responses in the findings were as follows: M231611 asserted: "Respect is gained by not being too aggressive towards others”. M211611 said: 'Junzi' [cultured people] are not aggressive and don't assert themselves too much, only small-minded people (Xiaoren) do”. M171511 noted: “In a dispute, I believe, I will gain more, particularly (with) my reputation as a 'junzi', if I retreat a bit to allow a solution to be reached". Older participants articulated such sentiments in Chinese sayings. For example, M1401311 said: “Tui yibu, haikuo tiankong”, meaning, when parties are in a dispute, the opportunities to find a solution will be as boundless as the ocean and as high as the sky, if both parties 'retreat' or 'give way'. Another Chinese saying of a similar meaning mentioned by S100911 was: “Tui yibu, fengping langjing”, which means 'the wind will subside and waves will calm'. This expresses a belief that in an awkward situation it is possible to avoid confrontation if parties the retreat, suggesting that Chinese consumers may adopt such a non-confrontational strategy because they want to preserve their "junzi” image.

\section{Value Theme Five - Social Harmony}

The fifth theme relates to social harmony. Nearly a third of participants intimated a desire to relate to others in a harmonious manner in situations where disputes occur (see Table 1). When service fails, harmony may be attained if an aggrieved party shows goodwill, diplomacy, patience, understanding and tolerance towards the service provider and vice versa. For example, participant M051111 said that when a promised dining table was not reserved, he had shown understanding and 
gained goodwill from the maitre de and his staff. This was evidenced in the staff's diligence in caring for his party. In another case, the participant demonstrated patience and understanding towards the inexperienced staff for poor service by not confronting the staff member on the spot. Rather, in an effort to maintain decorum and harmony, the customer quietly spoke to the manager after the dinner, resulting in the matter being satisfactorily addressed and goodwill gained for both parties.

Figure 5 provides an illustrative case example of this value chain, where the attributes of service failure relate to the unavailability of rooms for an early check-in (despite an earlier promise of availability) and with no options offered (no service recovery). This had the consequence of raising the guest's worry level about her aged parents' health and, in turn, resulted in the participant feeling annoyed and disappointed. Although the hotel staff failed to execute a service recovery, the participant refrained from being too assertive, such as complaining strongly or demanding immediate resolution. When asked why she had displayed this demeanour, she replied that she desired to deal with others harmoniously and to avoid conflict. She said this was natural bahavior as it was encouraged in her Chinese upbringing.

Insert Figure 5 here

Common responses in this theme were as follows: M241811 said "I like to get on with others - an example would be, to have some understandings of the server's difficulty...perhaps they are busy, [I] think there’s usually a reason”. C041310 noted: "It's best to relate to staff in a harmonious way...I allow some leeway for mistakes, although I expect some answers [resolutions]”, while M111411 advised: "If you show goodwill and tolerance...you're more likely to get on well with them [staff] and get a 
quicker solution" or "If you extend goodwill and tolerance, people will reciprocate and things can be resolved peacefully".

This finding appears to suggest that Chinese customers have the proclivity to deal with others harmoniously, as interpersonal harmony is highly exhorted and valued in the Chinese Confucian culture (e.g., Cheu, 2000; Leys, 1997). This finding is consistent with other justice literature, which highlights the likely efficacy of strategies of interpersonal harmony involving compromises, such as mediation and negotiation, to resolve conflicts (see for example, Morris \& Leung, 2000).

\section{DISCUSSION AND IMPLICATIONS}

This research sought to provide insights into how Chinese consumers interpret and respond to unpleasant service events. Common themes with a strong Confucian cultural flavor emerged from the study, representing some important end values for the study's participants. These values appear to assert an influence on how participants' respond to service failure and service recovery situations. Five key themes were identified based upon the interviews.

A key theme to emerge is “face protection”. As noted, Chinese conceptions of "face” relate to the respectability people claim from others for their good general conduct and successful performance in life (Ho,1976; Hu, 1944), while Goffman’s (1967) universal concept of “face” is a form of impression management people use in social interactions. These conceptualizations suggest that customers' "face” is closely linked to their deeper psychological needs of ego and self-esteem, and when "face” is violated, customers will feel embarrassed, humiliated or ashamed (Ho, 1976). This phenomenon suggests that customers’ psychological needs are just as important as their physical needs and it is imperative for service firms to understand this 
(Schneider \& Bowen, 1995). The face-work (protecting self and others) situation is made even more complex when dealing with customers from diverse cultural backgrounds.

Although "face" is a universal phenomenon (Ho, 1976), it is particularly significant for Chinese people who put a great emphasis on interpersonal relationships and behavioral regulation (Hwang, 1987). Thus, interpersonal encounter situations demand sensitivity and sophisticated practice of ‘face-work’ (Chang \& Holt, 1994). The salience of 'face-work', as demonstrated in the present study, is vividly conveyed in a Chinese saying: 'A gentleman can be killed but cannot be humiliated' or 'shi ke sha, buke ru' (in Chinese) (Wee, 2001:188). In particular, a Chinese who is humiliated publicly by others, will suffer a loss of "face", which is worse than being killed, and the aggrieved person will neither forgive nor forget his/her perpetrator (Wee, 2001). The person's own aggressive behavior in public may also result in him/her losing “face” and even his/her in-group members losing “face” (Chang \& Holt, 1994).

Chinese may also be conscious of 'giving face' to others and expect others to “bao” (reciprocate positively) (Chang \& Holt, 1994). Those who cause others to lose “face” may be perceived as aggressive, while giving "face” to others may be seen as an 'act of consideration' (Yau, 1994). Thus, a Chinese person's willingness to compromise or not demand a better solution after a service failure can be perceived as giving "face". Such behavior is evident even in an instrumental tie type of relationship, such as a service encounter, when interacting with out-group members such as a service provider (Bond \& Hwang, 1987). However, such displays of compromise may not necessarily mean that the customer is satisfied with the exchange, so effort is needed to ensure the customer is being fairly reciprocated for 
his/her 'consideration’ or ‘flexibility’ with the arrangement. A firm’s attempt to reach an appropriate compromise may allow both parties in a service failure dispute to 'save face' and achieve a satisfactory outcome (e.g., Schutte \& Ciarlante, 1998). In summary, face work is a core value identified by interviewing Chinese consumers about service incidents. This value can be directly related to the construct of interactional justice and, particularly, to the work of Bies and Moag (1986). Appreciating the importance of face as a salient cultural predisposition is essential for hospitality service providers.

Another value theme is the issue of equity, which Chinese participants in the study expect when service failures arise. Equity means receiving the service quality for which customers have paid. This theme also relates to distributive justice and an understanding that fairness evolves from an appreciation of the equity rule. Bond \& Hwang (1987) have acknowledged the importance of the equity principle to Chinese, especially as a foundation for dealing with interactions of a temporary nature such a service encounter. Similarly, this equity rule of a constant ratio of inputs to outputs was found to exist in the results from the interviews. More specifically, three issues are gleaned from the findings. First, participants' equity conception seems to have its basis on Adams' (1965) equity theory, where customers compare their inputs and outcomes with referent others. Equity exists if they perceive the input to outcome ratio is similar to the referent others. Second, participants must have some value standards for comparison, which Van den Bos, Vermunt and Wilke, (1997) note would be difficult to find when other customer's outcomes in similar situations is unknown. Third, participants' common usage of words such as fair or just about service outcome suggests that they must also have in mind the concept of distributive justice, which is grounded in Adams' (1965) equity theory. The observation of 
Chinese people's cognition of justice seems to be consistent with Hwang's theory of Chinese power games that states Chinese will adopt a more equitable strategy when distributing resources between themself and the out-group, such as the type of relationship existing between customers and service providers (Bond \& Hwang, 1987). Consequentially, hospitality service firms must ensure that any service recovery tactic in kind or effort must be perceived as adequate and fair to the Chinese customers. Furthermore, customers should be informed of the firm's normal standard of compensation for the type of service failure concerned to ensure customers' perceptions of fairness.

Another theme that emerged from this study relates to customers' feeling of being valued as gauged by how they are being treated by the service providers. As the findings show, customers who were racially or socially discriminated felt devalued. Discrimination clearly violates the "ren” concept under which many Chinese people are brought up as well as the universally accepted right to human equality. " $\mathrm{Li}$ " (propriety, honesty, politeness) is a set of guiding principles, which Chinese people are taught to observe and which regulate their social behaviours and help them to exercise "ren”. Inculcated through familial and formal education since childhood, Chinese people who practice "li" are acutely aware of its existence in their daily social interactions (e.g., Bond \& Hwang, 1987). It is unsurprising that customers articulated feelings of being less valued as customers if service providers treated them impolitely or doubted their honesty when they complained. When service mistakes occurred, respondents also expected to be extended sincere apologies, which is also a practice of "Ii". Once again, much of the material reported by the interviewees can be seen in light of interactional justice terms. As Bies (2001) notes, a sense of injustice may arise because some forms of behaviour violate a sense of self. That is, a lack of 
effort to recover a service failure or rude treatment might result in the aggrieved person feeling that their very self-identity has been threatened. This is similar to the finding we report, whereby interviewees seemed to feel that poor treatment within the service failure context led to a sense of not being valued as a customer; of not being worthwhile as a person.

Finally, in terms of a sense of feeling valued, the extra effort extended to help customers in recovering from service failures conveys the message that the individual self (customer) is important to the firm. The implications for the firm are clear, in terms of customer satisfaction, word-of-mouth and repurchase intention, since effort to help others is highly valued in Chinese society, as attested to in this common Chinese saying: 'A generous effort attracts adoration, while a mischievous mouth attracts derision'. Once again, this theme demonstrated a relationship to interactional justice.

An underlying mechanism for the effective operation of many relationships for the Chinese is the need to create a harmonious relationship to ensure there is no violation of "face" need to self or others. Our results showed a constant referral to the need for maintaining or regaining social harmony within the service failure management process. It is acknowledged that this theme has a facilitating effect on face relations and the ability to maintain a “junz"” image. Interestingly, organizational leadership research has also revealed a desire for a leader who maintains a harmonious relationship with followers (Bond \& Hwang, 1987). As noted by Gao, Tng-Toomey, \& Gudykunst (1996), communication style behavior that is assertive can threaten the harmony of interpersonal interactions, which in turn can threaten “face”. As noted by Bond (1991, p. 83) "Honor the hierarchy first, your vision of truth second”; this quote implies the importance of a harmonious relationship over 
truth. The implication for service failure events is that the service provider (staff) should attempt to recognize the importance of the customer and ensure communication leads to the maintenance of harmony. Mattila and Patterson’s (2004) research into service failure and recovery also makes the point that East Asian cultures tend to avoid conflict and confrontation. They conclude that a cultural norm propels Asians to maintain harmonious relationships in hospitality service encounter contexts.

The last theme, relates to Chinese customers' aspirations to adopt a “junzi” behavior and is partially intertwined with the last theme of seeking social harmony. In situations of hospitality service failures, customers’ interests may be disadvantaged and opportunities for hostile confrontations often arise, posing threats to guests' “junzi” (self image) and feelings of social harmony. Chinese are often taught from a young age to behave like a "junzi" (a benevolent person) and to relate to others harmoniously, as opposed to being a non-benevolent person (Cheu, 2000). He/she is taught to practice "ren” (benevolence) towards others. The Chinese concept, "ren”, was developed by Hsu (1971b) to elucidate the reality of people and their behavior. He explains that people have social, security and status needs, and these are fulfilled through their positive, harmonious transactions with others. "Ren" is central to the core of humans, which Hsu (1971b) chose to mean 'men' to explain their reality and behaviors. Thus, a "junzi" is expected to relate to others benevolently, showing kindness, tolerance, goodwill, understanding and harmony. Therefore, customers who behave in a 'junzi' manner may be motivated by "ren” to modify their behaviors to avoid unpleasant confrontations in service exchange breakdowns. Moreover, they may avoid being too direct or openly aggressive in their demand for fair compensations and to avoid creating disharmony in public, which can damage their "junzi” image. 
However, as previously stated, a customer's non-aggressive demeanor should not be interpreted as their satisfaction with the outcome. If service failures are not rectified or dealt with in a satisfactory manner, negative word-of-mouth is still likely to be spread. A pro-active tourism or hospitality firm should attempt to find the cause of a failure and instigate appropriate measures to regain customers’ confidence.

The discussion above has provided an examination of themes representing Chinese cultural values prevalent in the sample of Chinese participants taken from three countries, and provided some insights for firms to leverage for service management strategies. In developing service recovery processes for international tourists it is vital to build an understanding of culturally determined perceptions of failure events. Of particular relevance is the need to understand the sensitivity required in handling a service failure event. Service personnel must appreciate that when dealing with Chinese, it is important to maintain a harmonious interaction and to not blame the customer. Similarly, adopting a polite demeanour throughout the interaction is important to create harmony. An emphasis upon the interpersonal treatment of service encounters is an important service recovery tactic. Those firms targeting Chinese tourists could consider conducting workshops for staff on how cultural norms drive complaint behaviour. In particular, an understanding of the concept of "face" and the related behaviors that Chinese adopt to maintain "face" would be important. This paper has provided such insight using a means ends approach to uncovering the deeper values that tend to be violated in service failures.

\section{FUTURE RESEARCH, LIMITATIONS AND CONCLUSIONS}

This study used a convenience sample of participants for the interviews and may not be completely representative of the broad population, although attempts were 
made in the convenience sample to select a cross-section of the study population in these source markets. Clearly, studies utilizing samples from other countries with large Chinese communities, such as Hong Kong and Taiwan, may be necessary to confirm findings in the present study. A further test of some of the key findings using other methodologies may also be recommended to ensure insights gained have high reliability. For instance, scenario studies testing the role of various settings (e.g. restaurant versus hotel), levels of severity (extreme or minor) as well as locus or stability of the service failure (internal or external to the firm; one off event versus double deviation) would provide much needed insight into the cause and effect issue within a Chinese cultural context. Similarly, survey research using quantitative measures representing the value themes identified in the present research would be useful to test whether the five dimensions exist when subject to psychometric analyses. Furthermore, such analyses could test the relative importance (or hierarchy) of each value theme.

The above-discussed Confucian doctrines and their normative guiding principles may be connected with many behavioral dispositions found among Chinese people. Dispositions such as face protection, equity, harmony maintenance, conflict avoidance and the like, represent a tendency for a person to behave in accordance with external expectations and norms, rather than to be always motivated by personal integrity. These behavioral dispositions allow an individual to protect a social self and function integrally in society. The interviews revealed overwhelming support for the importance of interactional justice as a potential threat to many of the core values. As Mattila and Patterson (2004) observe, people from East Asian cultures often have an interdependent view of self. As a result, interactions with others are a salient measure of one's own self worth. The implication for hospitality service providers is to 
manage service interactions efficaciously and assiduously in order to meet Chinese customers' needs and expectations. An emphasis on interactive dimensions of the service encounter seems especially important but challenging in an international tourism context. 


\section{References}

Adams, S. J. (1965). Toward an understanding of inequity. Journal of Abnormal and Social Psychology, 67(5), 422-36.

Becker, C. (2000). Service recovery strategies: The impact of cultural differences. Journal of Hospitality \& Tourism Research, Vol. 23(3), 526-538.

Becker, C., Murrmann, S.K., Murrmann, K.F., \& Cheung, G.W. (1999). A pancultural study of restaurant service expectations in the United States and Hong Kong. Journal of Hospitality \& Tourism Research, 24(4), 526-538.

Berry, L. L. (1995). On great service - a framework for action. The Free Press.

Bies, R. J. (2001). Interactional (in)justice: The sacred and the profane. In J. Greenberg \& R. Cropanzano (Ed.), Advances in Organizational Justice, California: Stanford University Press.

Bies, R. J., \& Moag, J. S. (1986). International justice: Communication criteria for fairness. In B. Sheppard (Ed.), Research on Negotiation in Organizations, 1, 43-55. Greenwich, CT: JAI Press.

Blodgett, J. G., Hill, D. J., \& Tax, S. S. (1997). The effects of distributive, procedural, and interactional justice on post-complaint behavior. Journal of Retailing. 73(2), 185-210.

Bond, M. H. (1991). Beyond the Chinese face: Insights from psychology. Hong Kong: Oxford University Press.

Bond, M. H. (1996). Chinese values. In M.H.Bond (Ed.), The Handbook of Chinese Psychology. Oxford University Press Hong Kong. 
Bond, M. H., \& Hwang, K. K. (1987). The social psychology of Chinese people. In M.H.Bond (Ed.), The psychology of the Chinese people. Oxford University Press (China) Ltd. China.

Chang, H.. C., \& Holt, G.R. (1994). A Chinese perspective on Face as inter-relational concern. In Ting-Toomey (Ed.), The Challenge of Face work - Cross-cultural and Interpersonal Issues, State University of New York Press.

Cheu, H.T. (2000). Confucianism in Chinese culture. Pelanduk Publications.

Chinese Culture Connection (1987). Chinese values and the search for culture-free dimensions of culture, Journal of cross-cultural psychology. 18, 143-164.

Chiu, C.Y., Tsang, S.C., \& Yang, C.F. (1987). The role of face situation and attitudinal antecedents in Chinese consumer complaint behavior. The Journal of Social Psychology, 128(2), 173-180.

Clarke, T. (1990). International marketing and national character: A review and proposal for an integrative theory. Journal of Marketing, 54, 66-78.

Collie, T., Sparks, B. A., \& Bradley, G. L. (2000). Investing in interactional justice: A study of the fair process effect within a hospitality failure context. Journal of Hospitality and Tourism Research, 24(4), 448-472.

de Mooij, M, (1998). Global marketing and advertising: Understanding cultural paradoxes. Thousand Oaks, CA: Sage.

Fan, Y. (2000). A classification of Chinese culture. Cross cultural management - an International Journal. 7(2), 3-10.

FitzGerald, H. (2002). Cross-Cultural Communication for the Tourism and Hospitality Industry, 52-66. Pearson Education Australia. 
Gao, G., Tng-Toomey, S., \& Gudykunst, W. B. (1996). Chinese Communication Processes. In M. H. Bond, The Handbook of Chinese Psychology, Hong Kong: Oxford University Press.

Goodwin, C., \& Ross, I. (1989). Salient dimensions of perceived fairness in resolution of service complaints. Journal of Customer Satisfaction/Dissatisfaction and Consumer Behavior. 2, 87-92.

Goffman, E. (1967). Interaction ritual: Essays on face-to-face interaction. Garden City, NY: Doubleday.

Hofstede, G. (1980). Culture's consequences: International differences in workrelated values. Newbury, CA:Sage.

Ho, D.Y.F. (1976). On the concept of face. American Journal of Sociology. 81(4), 867-884.

Hsu, F. L. K. (1971b), Psychosocial Homeostasis and Jen: Conceptual tools for advancing psychological anthropology. American Anthropology, 73, 23-44.

Hu, H. C. (1944). The Chinese concepts of 'face’, American Anthropologist, 46, 4564

Hui, K. K., \& Au, K. (2001). Justice perceptions of complaint-handling - A crosscultural comparison between the PRC and Canadian customers. Journal of Business Research 52, 161-173.

Hwang, K. K. (1987). Face \& favor: The Chinese power game, American Journal of Sociology, 92, 944-74.

Johnston, R. (1995). Service Failure and Recovery: Impact, Attributes and Process. In T.A. Swartz, D.E. Bowen, and S.W. Brown (Eds.), Advances in Services Marketing and Management Research and practice, 4 (211-228). Greenwich, CT: JAL Press. 
Johnson, R., \& Fern, A. (1999). Service recovery strategies for single and double deviation scenarios. The Services Industries Journal, 19(2), 69-82.

Kindle, T. I. (1982). A partial theory of Chinese consumer behavior: Marketing strategy implications. Hong Kong Journal of Business management, 1, 97-109.

Kluckhohn, F. R., \& Strodbeck, F. L. (1961). Variations in value orientation. Row, Paterson and Co. Illinois.

Lewis, R.C., \& Chambers, R.E. (1989). Marketing Leadership in Hospitality: Foundations and Practices. Van Nostrand, New York.

Leys, S. (1997). The Analects of Confucius. W.W. Norton \& Company, New York.

Liu, T. C., Warden, C.A., Lee, C. H., \& Huang, C. T. (2001). Fatal service failures across cultures. Journal of Hospitality \& Leisure Marketing, 8(1/2), 93-110

Magnini, V. P., \& Ford, J. B. (2004). Service recovery in China. International Journal of Contemporary Hospitality Management, 16(5), 279-286.

Mattila, A. S. (1999). The role of culture and purchase motivation in service encounter evaluations. Journal of Services Marketing, 13(4/5).

Mattila, A. S., \& Patterson, P. G. (2004). Service recovery and fairness perceptions in collectivist and individualist contexts, Journal of Service Research, 6(4), 336346.

McColl-Kennedy, J. R., \& Sparks, B. A. (2003). Application of fairness theory to service failures and service recovery, Journal of Service Research. 5(3), 251266.

Morris, M. W., \& Leung, K. (2000). Justice for all? Progress in research on cultural variation in the psychology of distributive and procedural justice. Applied Psychology: An International Review, 49(1), 100-132. Blackwell Publishers. 
Phang, H. E, (2000). The Economic Role of the Chinese in Malaysia. In Lee K, H., \& Tan C. B (Eds.), The Chinese in Malaysia, 94-120. Oxford University press. Reisinger, Y., \& Turner, W. L. (2003). Cross-cultural behaviour in tourism: concepts and analysis, Butterworth Heinmann,

Reynolds, J., \& Gutman, J. (1988). Laddering theory, method, analysis, and interpretation. Journal of Advertising Research, 11-31.

Schneider, B., \& Bowen, D. E. (1995). Winning the service game, Harvard business School, Boston, Massachusetts.

Schutte, H. \& Ciarlante, D. (1998). Consumer Behaviour in Asia. Macmillan Business.

Sparks, B. A. (2003). "Waiter, what's that fly doing in my soup?...Responding to service failure in the hospitality industry”. 2003 Professorial Lecture Series. $19^{\text {th }}$. June. 2003. Griffith University.

Tan, C. T., \& McCullough, J. (1985). Relating ethnic attitudes and consumption values in an Asian context. In E.C.Horschman., \& H.B. Holbrook (Eds.), Advances in Consumer Research, XII. (Provo, UT: Association for Consumer Research, 1985).

Tan, T. W. (1998). Your Chinese roots - The overseas Chinese story. Times Book International, Singapore and Kuala Lumpur.

Tax, S. S., Brown S. W., \& Chandrashekaran, M. (1998). Customer evaluations of service complaint experiences: Implications for relationship marketing. Journal of Marketing, 62, 60-76.

Thorelli, H. B. (1982). China: consumer voice and exit. In R.L. Day \& H.K. Hunt (Eds.), International fare in Consumer Satisfaction and Complaining. Papers from the Seventh Annual Conference on Consumer satisfaction, dissatisfaction and complaining behavior, University of Tennessee, Knoxville, Tennessee, 
October 17-19 (1982). Department of Marketing, School of Business Indiana University, Bloomington, Indianapolis 105-11

Titz, K (2001). The Impact of people, process, and physical evidence on tourism, hospitality, and leisure service quality. In J. Kandampully, C. Mok, \& B.A. Sparks, (Eds.), Service Quality Management in Hospitality Tourism and Leisure. The Haworth Hospitality Press, Binghamton, NY.

Tse, D., Lee, K., Vertinsky, H., \& Wehrung, D. (1988). Does culture matter: A crosscultural study of executives' choice decisiveness, and risk adjustment in international marketplace. Journal of Marketing, Vol. 52, 81-95.

Van den Bos, K.R., Vermunt, K. R., \& Wilke, H. A. H. (1997). Procedural and distributive justice: what is fair depends more on what comes first than on what comes next, Journal of Personality and Social Psychology, 49, 341-359.

Warden, C. A., Liu, T.C., Huang, C. T., \& Lee, C. H. (2003). Service failures away from home: benefits in intercultural service encounters. International Journal of Service Industry management. 14(4). 436-457.

Wee, C. H. (2001). The inspirations of Tao Zhu-gong - Modern business lessons from an ancient past. Prentice Hall, Singapore.

Wong, N. Y. (2004). The role of culture in the perception of service recovery, Journal of Business Research 57(9), 957-963.

Wong, S., \& Lau, E. (2001). Understanding the behavior of Hong Kong Chinese Tourists on Group Tour Packages. Journal of Travel Research, 40 (August), 57-67.

World Tourism Organization (2003). Chinese Outbound Tourism, Madrid, Spain. 1160. 
Yang, C.F., Ho, S.C., \& Yau, H.M. (1989). Hong Kong marketing management at the crossroads: A case analysis approach. The Commercial Press (Hong Kong) Ltd. Hong Kong.

Yau, O.H.M. (1994). Consumer behavior in China - Customer satisfaction and cultural values. Routledge, London and New York.

Yuksel, A., Kilinc, U. K., Yuksel, F. (2006). Cross-national analysis of hotel customers' attitudes toward complaining and their complaining behaviors. Tourism Management, 27, 11024. 
Table 1

Common Value Themes ${ }^{1}$

\begin{tabular}{|c|c|c|c|c|c|c|c|c|c|}
\hline \multicolumn{2}{|c|}{$\begin{array}{l}\text { FACE WORK } \\
\text { Count: } 30\end{array}$} & \multicolumn{2}{|c|}{$\begin{array}{l}\text { EQUITY } \\
\text { Count: } 23\end{array}$} & \multicolumn{2}{|c|}{$\begin{array}{l}\text { VALUED CUSTOMER } \\
\text { Count: } 19\end{array}$} & \multicolumn{2}{|c|}{$\begin{array}{l}\text { SOCIAL HARMONY } \\
\text { Count: } 17\end{array}$} & \multicolumn{2}{|c|}{$\begin{array}{l}\text { JUNZI } \\
\text { Count: } 16\end{array}$} \\
\hline Value & Count & Value & Count & Value & Count & Value & Count & Value & $\begin{array}{c}\text { Coun } \\
t\end{array}$ \\
\hline Reputation & 6 & Just treatment & 3 & Apology & 3 & Not confronting & 2 & Respect & 3 \\
\hline Other's image & 4 & Fair exchange & 3 & Effort to help & 2 & Get on & 2 & Cultured & 3 \\
\hline Mianzi (face) & 5 & Moderation & 5 & Honesty & 2 & Accommodate & 2 & Gentleman & 3 \\
\hline Good character & 6 & Discriminated & 3 & Politeness & 3 & Compromise & 2 & Compassion & 2 \\
\hline Dignity & 6 & Exploited & 2 & Buyer's rights & 3 & Not aggressive & 2 & Deference & 2 \\
\hline Family name & 2 & Unfair return & 3 & To be valued & 4 & Peace (He) & 2 & Junzi image & 2 \\
\hline Public image & 2 & Had to paid more & 1 & Trusted & 2 & Goodwill & 2 & Self-control & 1 \\
\hline Shame & 2 & Inferior value & 2 & & & Cordiality & 1 & & \\
\hline Integrity & 2 & Met half-way & 1 & & & Reciprocity (bao) & 1 & & \\
\hline Honor & 1 & & & & & Diplomacy & 1 & & \\
\hline
\end{tabular}

\begin{tabular}{|c|c|c|c|c|c|c|c|c|c|}
\hline Consequences & Count & Consequences & Count & Consequences & Count & Consequences & Count & Consequences & $\begin{array}{c}\text { Coun } \\
t\end{array}$ \\
\hline Looked down on & 4 & Felt cheated & 3 & Felt anxious & 2 & Indignation & 3 & Upset & 3 \\
\hline Insulted & 4 & Felt exploited & 3 & Felt angry & 4 & Poorly served & 2 & Disappointed & 2 \\
\hline Humiliated & 3 & Humiliation & 4 & Indignation & 5 & Offended & 1 & Tolerance & 2 \\
\hline Embarrassed & 3 & Angry \& upset & 4 & Annoyance & 2 & Disappointed & 3 & Accepting & 2 \\
\hline Ignored & 1 & Unfair treatment & 3 & Disappointed & 4 & Annoyance & 3 & Undignified & 3 \\
\hline Unpleasant & 3 & Deprivation & 2 & Threatened & 3 & Parents' health & 2 & Don't argue & 2 \\
\hline Public scene & 2 & Disappointed & 3 & Discriminated & 2 & Retreat a step & 3 & Practise 'li' & 2 \\
\hline *Angry/upset & 4 & Annoyance & 2 & Felt insulted & 2 & Inconvenienced & 3 & Negotiation & 1 \\
\hline Felt stupid & 3 & Anxiety & 1 & Offended & 1 & Felt helpless & 1 & Understand & 2 \\
\hline Being blamed & 2 & Dissatisfaction & 2 & Inconvenienced & 3 & Avoid conflict & 4 & Disadvantaged & 2 \\
\hline Long wait & 1 & Spoiled event & 2 & Lied to & 2 & Plead for help & 2 & Inconvenienced & 3 \\
\hline Inconvenienced & 2 & Less activity & 2 & Neglected & 2 & Long wait & 2 & Long wait & 2 \\
\hline Delayed & 3 & Little rest & 2 & Second-rate & 1 & Felt neglected & 2 & Discomfort & 1 \\
\hline Threatened & 1 & Discomfort & 1 & Insincerity & 2 & Short-changed & 1 & Neglected & 1 \\
\hline Spoiled event & 2 & Limited service & 2 & No rights & 2 & & & & \\
\hline Self control & 2 & Discriminated & 2 & Let down & 1 & & & & \\
\hline Loss of face & 2 & Had to haggle & 1 & & & & & & \\
\hline
\end{tabular}

\begin{tabular}{|c|c|c|c|c|c|c|c|c|c|}
\hline Service attributes & Count & Service attributes & Count & Service attributes & Count & Service attributes & Count & Service attributes & $\begin{array}{c}\text { Coun } \\
t\end{array}$ \\
\hline Won't listen & 1 & No negotiation & 1 & Abusive chef & 1 & Uncaring staff & 2 & Slow service & 2 \\
\hline Slow service & 3 & Slow service & 3 & Slow service & 1 & Slow service & 1 & Faulty service & 2 \\
\hline Late service & 4 & Faulty service & 4 & Faulty service & 2 & Faulty service & 2 & Rude staff & 2 \\
\hline Faulty service & 3 & Bad recovery & 2 & Bad recovery & 1 & Rude staff & 2 & Discriminated & 2 \\
\hline Bad recovery & 2 & Rude staff & 2 & Rude staff & 2 & Discriminated & 1 & Broken promise & 1 \\
\hline Rude staff & 5 & Discriminated & 2 & Discriminated & 2 & Broken promise & 1 & Mistakes & 1 \\
\hline Discriminated & 3 & Broken promise & 3 & Broken promise & 2 & Mistakes & 2 & Unethical ways & 2 \\
\hline Broken promise & 2 & Mistakes & 4 & Mistakes & 2 & Unethical ways & 1 & No reservation & 1 \\
\hline Mistake & 2 & Unethical ways & 2 & Unethical ways & 1 & Rigid policy & 1 & Inferior room & 2 \\
\hline Unethical ways & 2 & Rigid policy & 2 & Rigid policy & 2 & Late service & 2 & Hostile staff & 1 \\
\hline Rigid policy & 2 & Inferior room & 1 & Insincere staff & 2 & Sarcastic staff & 1 & Misinformed & 2 \\
\hline Misinformed & 2 & Cold staff & 2 & No Booking & 2 & Hostile staff & 1 & Uncaring staff & 2 \\
\hline No help given & 2 & Long queue & 1 & & & & & & \\
\hline Wrong bill & 1 & & & & & & & & \\
\hline Uncaring staff & 3 & & & & & & & & \\
\hline
\end{tabular}




\section{Appendix 1 Glossary of Terms}

\begin{tabular}{|c|c|}
\hline Chinese Term & Definition \\
\hline Bao & $\begin{array}{l}\text { A Chinese concept of 'repayment' which has a positive outcome } \\
\text { when an individual repays a favor owed to others (reciprocity), } \\
\text { and also a negative outcome when an aggrieved individual } \\
\text { entrusts his/her avenge to the 'heavens' to punish the wrong- } \\
\text { doer (retribution). }\end{array}$ \\
\hline Face Protection & $\begin{array}{l}\text { Refers to the attempt an individual makes to act or behave in a } \\
\text { manner that will protect or 'save' his/her 'Lian' and 'Mianzi'. } \\
\text { An individual's 'face' may be given protection or he/she may } \\
\text { act to give protection to other's 'face', known as 'giving face' } \\
\text { (gei 'Mianzi'). An individual who fails to protect his/her 'face' } \\
\text { or is not being given 'face' may suffer a 'loss of face' (diu 'lian' } \\
\text { or 'mianzi'). }\end{array}$ \\
\hline Face & $\begin{array}{l}\text { Conceptualized in Chinese culture as 'lian' and 'mianzi'. 'Lian' } \\
\text { represents the 'moral character' of an individual, which can be } \\
\text { lost when he/she violates the moral standards of society, losing } \\
\text { society's trust and respect, while 'mianzi' is the 'social prestige' } \\
\text { and 'honour' which an individual may claim from society } \\
\text { through his/her achievement and success in life. }\end{array}$ \\
\hline Jia Jiao & $\begin{array}{l}\text { The teaching of culture and acceptable ways of behavior to } \\
\text { children by adult family members. }\end{array}$ \\
\hline Jie & $\begin{array}{l}\text { 'To exercise restraint', often linked to the Chinese term } \\
\text { 'Zhongyung' or 'to exercise moderation'. }\end{array}$ \\
\hline Junzi & $\begin{array}{l}\text { A cultured or perfect individual who fully possesses the virtues } \\
\text { of compassion, kindness and other benevolent qualities towards } \\
\text { fellow human beings (known as 'ren'). The opposite to the } \\
\text { 'Junzi' character of an individual is 'Xiaoren' or an ignoble } \\
\text { character. }\end{array}$ \\
\hline$L i$ & $\begin{array}{l}\text { The rites and rituals (ritual propriety) which guide an individual } \\
\text { in a hierarchical and role relationship to do the proper things } \\
\text { with the right people in the appropriate relationships, while }\end{array}$ \\
\hline
\end{tabular}




\begin{tabular}{|c|c|}
\hline & $\begin{array}{l}\text { 'Limao' refers to an individual's socially acceptable behavior, } \\
\text { e.g. politeness. }\end{array}$ \\
\hline Shi ke sha, buke ru & $\begin{array}{l}\text { A Chinese saying meaning 'a gentleman can be killed but } \\
\text { cannot be humiliated'. In other words, a Chinese person who } \\
\text { suffers a loss of face by being humiliated in public is worse than } \\
\text { being killed. }\end{array}$ \\
\hline $\begin{array}{l}\text { Tui yibu, fengping } \\
\text { langjing }\end{array}$ & $\begin{array}{l}\text { 'The wind will subside and waves will calm', suggesting that a } \\
\text { confrontation can be avoided if parties show refrain. }\end{array}$ \\
\hline $\begin{array}{l}\text { Tui yibu, haikuo } \\
\text { tiankong }\end{array}$ & $\begin{array}{l}\text { A Chinese saying which suggests that the space to resolve a } \\
\text { problem will be as wide as the ocean and as high as the sky if } \\
\text { parties to a dispute retreat a step or in other words, 'give in a } \\
\text { bit'. }\end{array}$ \\
\hline Zhonghe & $\begin{array}{l}\text { An individual who behaves in a reasonable and harmonious } \\
\text { manner. }\end{array}$ \\
\hline
\end{tabular}




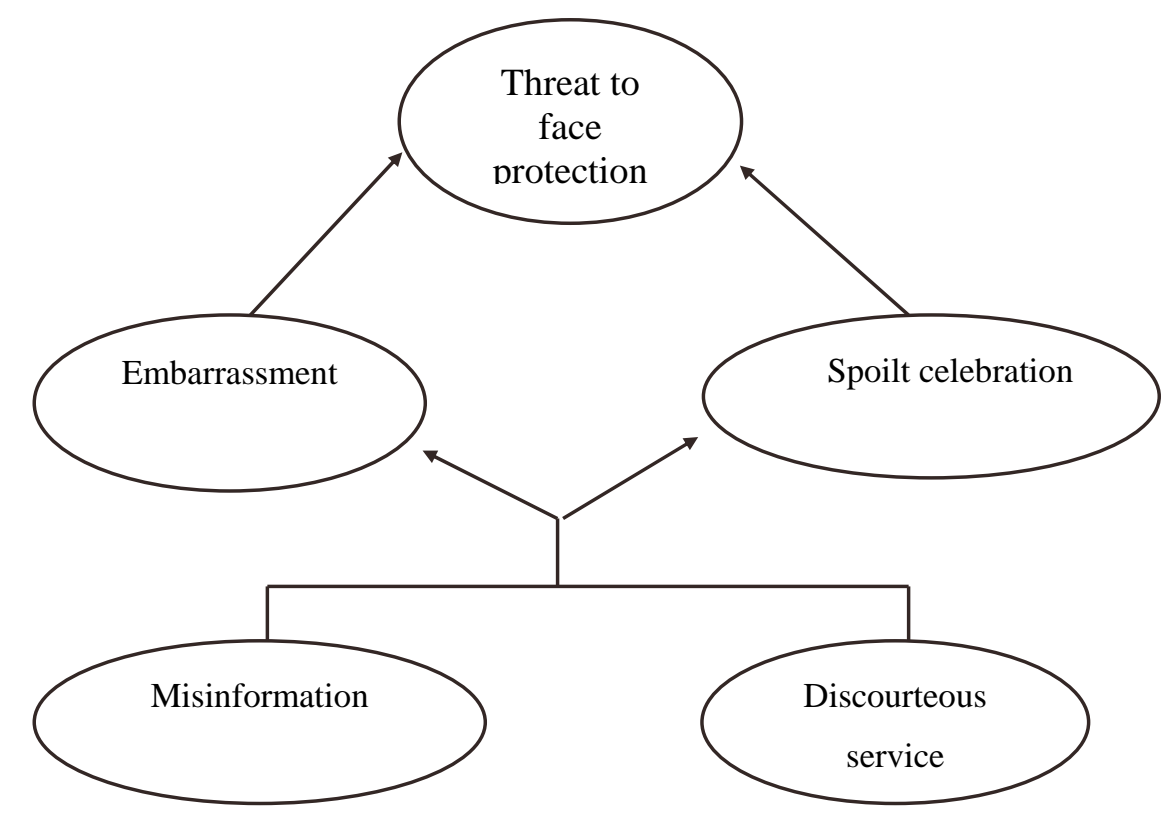

Figure 1: Illustrative chain for "face protection" 


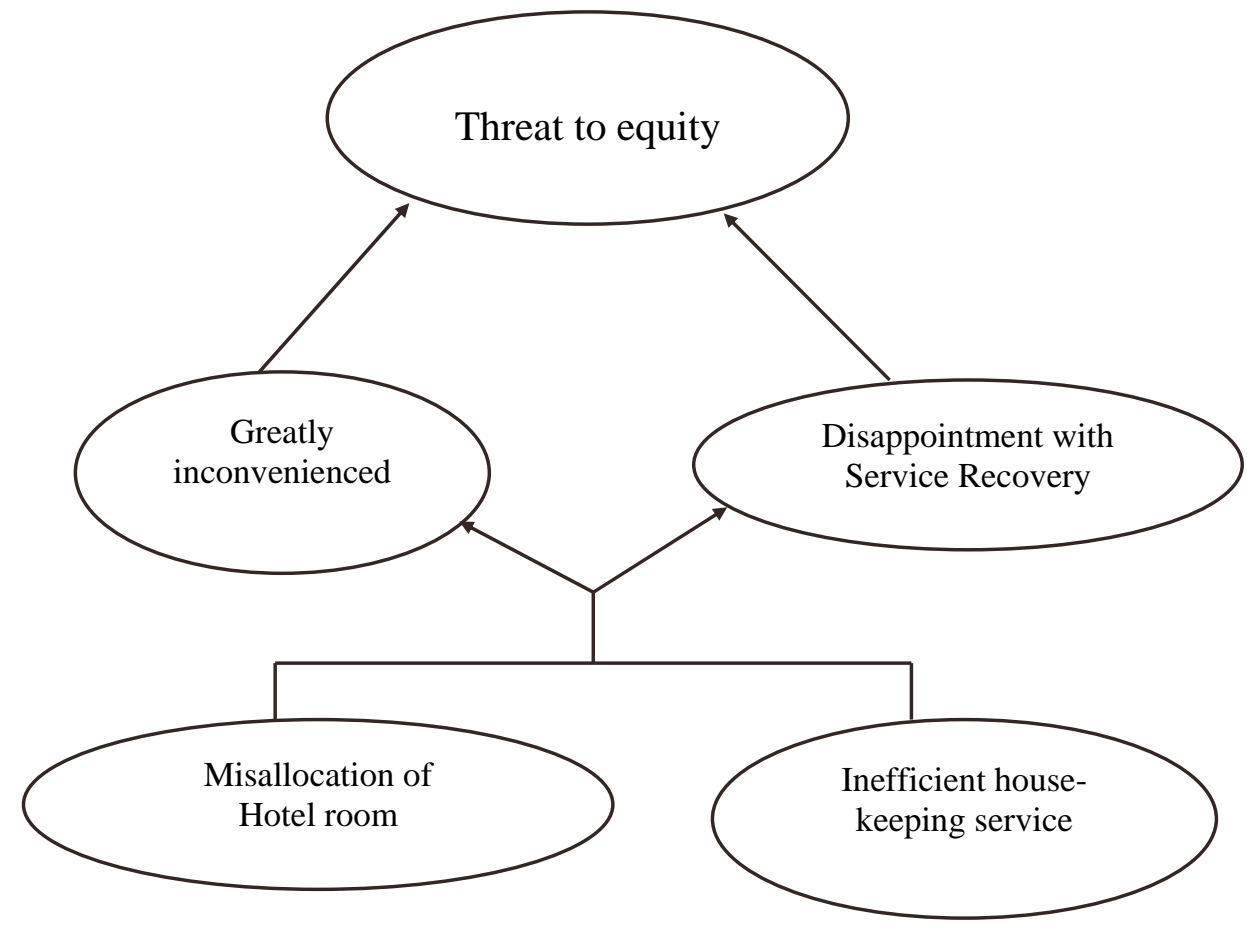

Figure 2: Illustrative chain for "equity" 


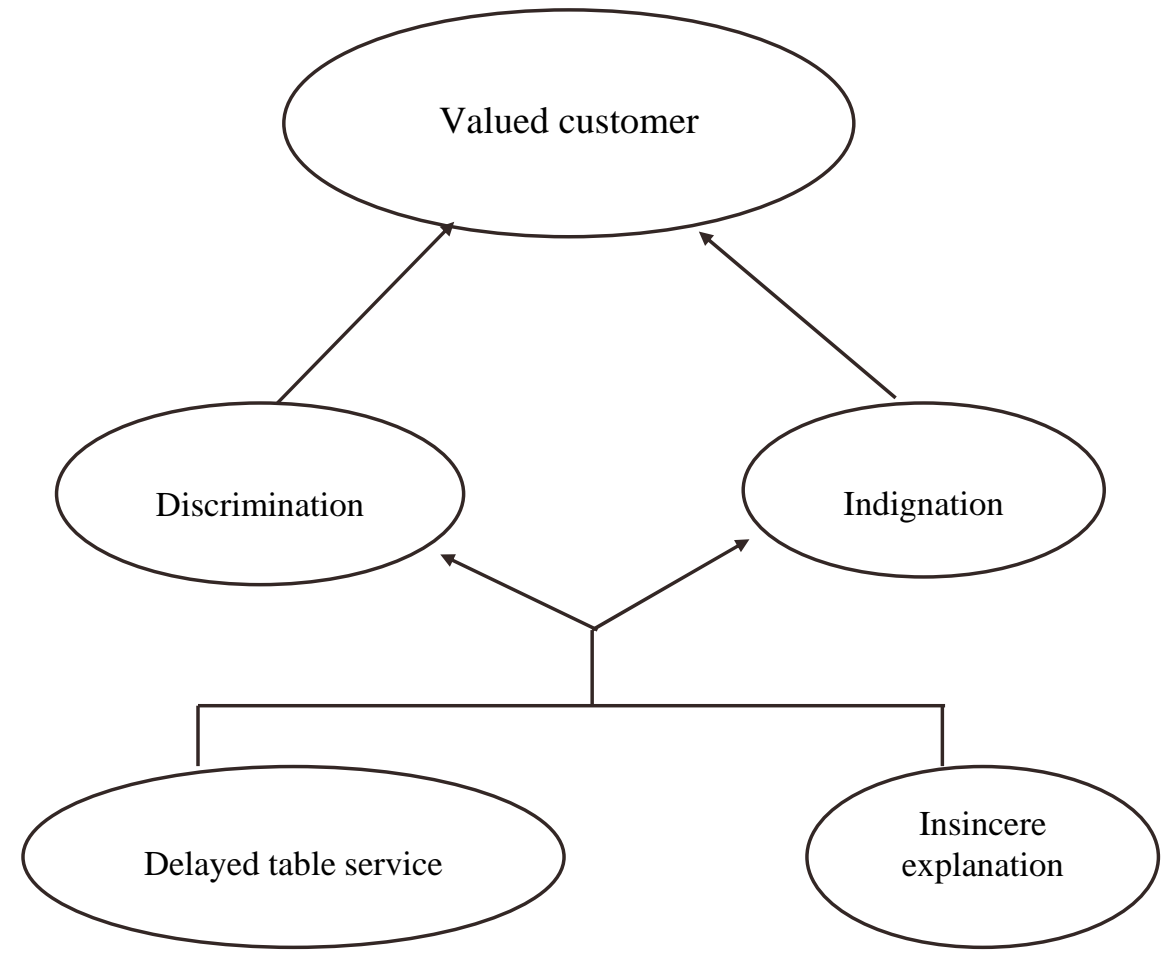

Figure 3: Illustrative chain for "valued customers" 


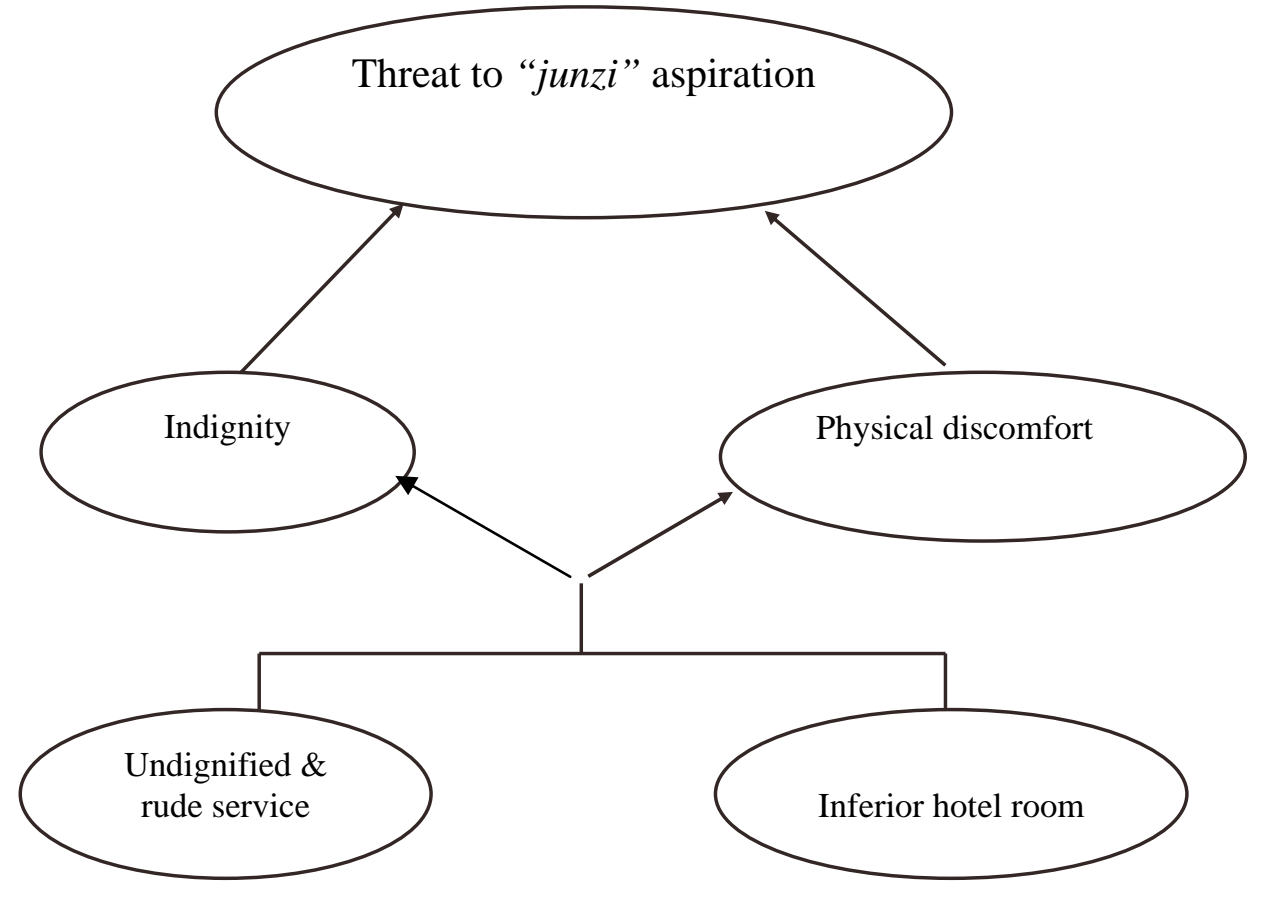

Figure 4: Illustrative chain for "junzi” aspiration 


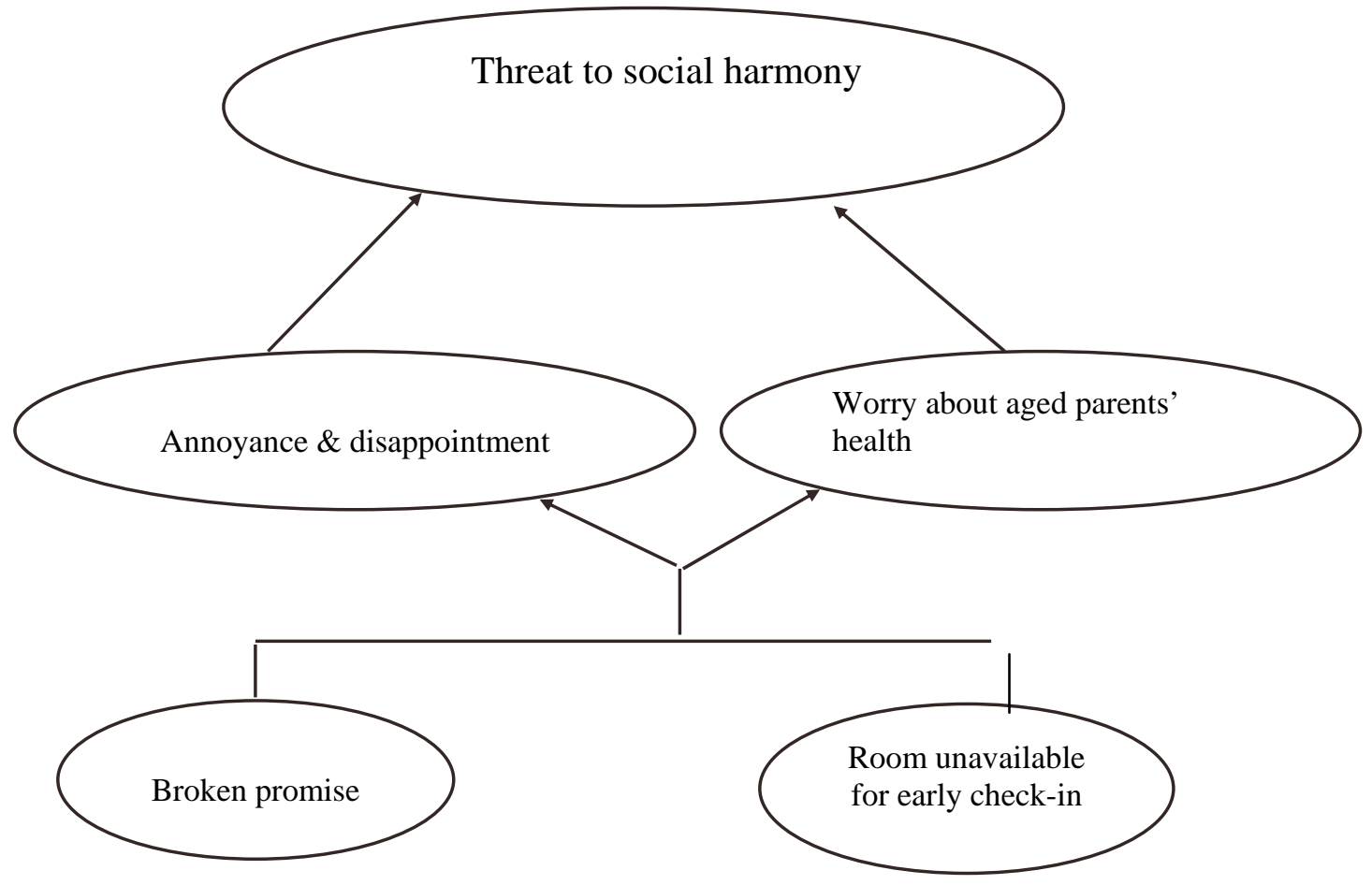

Figure 5: Illustrative chain for "social harmony" 
